\title{
ステンレス鋼のコーキシング効果に及ぼす予ひずみの影響
}

\section{Influence of Prestrain on Coaxing Effect in Austenitic Stainless Steel}

\author{
学 ○鄭 在雄 (岐阜大院) 正 中島 正貴（豊田高専）正 秋田 正之（岐阜大工） \\ 正 植松 美彦 (岐阜大工) 正 戸梶 惠郎 (岐阜大工)
}

\begin{abstract}
Jae-Woong JUNG Graduate Student, Gifu University, Masaki NAKAJIMA, Toyota National College of Technology
\end{abstract} Masayuki AKITA, Yoshihiko UEMATSU, Keiro TOKAJ, Gifu University

Key Words: Fatigue, Prestrain, Strain induced phase transformation, Austenitic stainless steel, Coaxing effect

\section{1. 緒言}

疲労限度直下の忘力を繰返し，その後応力を階段的に増 加していくとコーキシング効果により破断応力が著しく上 昇することが知られている.これまでにコーキシング効喿 の発現メカニズムとして，冷間加工による強化，ひずみ時 効, およびすべり帯き裂先端の強化等が提唱されているが, 依然として不明な点が多い.

そこで本研究では，オーステナイト系ステンレス鋼 SUS304 およびSUS316 用いて応力漸増試験を行い, 得ら れた結果に基づいてコーキシング効果に及ぼす予ひずみの 影響とそのメカニズムについて検討した。

\section{$2 \cdot 1$ 供試材および試験片形状}

\section{2. 実 験 方 法}

供試材はオーステナイト系ステンレス鋼 SUS304 および SUS316 である. 溶体化処理後の機械的性質を Table 1 に示 寸，用いた疲労試験片の形状は砂時計型であり，最小断面 部直径は SUS304 では $5.5 \mathrm{~mm}$, SUS316 では $5 \mathrm{~mm}$ である. 素材に所定の引張予ひずみを付与したのち、試験片形状に 機械加エした。 その後, エメリー紙で 2000 番まで研磨し, さらにバフ研磨を施して試験に供した。

\section{$2 \cdot 2$ 実験方法}

試験には片持回転曲げ疲労試験機を用いた。ビッカース 硬さ計を用いて応力漸増の前後の硬さを測定した．き裂発 生の観察にはレプリカ法を用い，応力を上昇させる度に試 験片表面のレプリカを採取した．採取したレプリカから光 学顕微鏡を用いてき裂の有無の確認を行った.また試験後, 走查型電子顕微鏡 (SEM) を用いて破面を詳細に観察した. ひずみ時効能の確認のために，万能型引張試験機を用いて 引張試験を行った。 また，X線回折装置を用いて加工誘起 マルテンサイト変態を測定した.

\section{3. 実 験 結 果}

\section{$3 \cdot 1$ 疲労強度}

SUS304 おうよび SUS316の S-N 曲線を Fig.1 に示す. 無予 ひずみ材の場合，有限寿命領域の疲労強度は SUS304 のほ うがやや高いが，疲労限度に差異はなく $300 \mathrm{MPa}$ である. 図から明らかなように，両材とも予ひずみ量の増加に伴っ て疲労強度は上萃する。疲労限度は SUS304 の場合, $30 \%$ 予ひずみ材では $440 \mathrm{MPa}, \sigma_{\mathrm{B}}$ 予ひずみ材では $470 \mathrm{MPa}$ であ る。また, SUS316の場合，疲労限度は 5\%予ひずみ材では $320 \mathrm{MPa}, 15 \%$ 予ひずみ材では $380 \mathrm{MPa}, 25 \%$ 予ひずみ材で は $420 \mathrm{MPa} ， \sigma_{\mathrm{B}}$ 予ひずみ材では $460 \mathrm{MPa}$ である。

\section{$3 \cdot 2$ 応力漸增試験結果}

Fig.2 および Fig.3 に SUS304 と SUS316 の応力漸増試験 結果をそれぞれ示す。図から明らかなように，破断応力は SUS304 の場合，無予ひずみ材では 540MPa，30\%予ひずみ
材では $580 \mathrm{MPa} ， \sigma_{\mathrm{B}}$ 予ひずみ材では $630 \mathrm{MPa}$ である.また SUS316 の場合, 無ひずみ材では $360 \mathrm{MPa}, 5 \%$ 予ひずみ材 では $400 \mathrm{MPa}, 15 \%$ 予ひずみ材では $400 \mathrm{MPa}, 25 \%$ 予ひずみ 材では $480 \mathrm{MPa} ， \sigma_{\mathrm{B}}$ 予ひずみ材では $560 \mathrm{MPa}$ である。この ように, SUS304 の場合, 予ひずみの増加に伴って破断応 力は増加する。一方 SUS316 の場合, 15\%予ひずみ材では 一旦顕著な破断応力の増加は見られなくなるが, その後予 ひずみの増加に伴って再び破断応力は増加する. なお, 両 材の全ての試験片において停留き裂は観察されなかった。

$3 \cdot 3$ 硬さ測定

忘力漸増の前後で硬さの測定を行った。その結果を Table 2 に示す. 試験後, 両材とも予ひずみにかかわら音硬さは 上昇する.この結果から，コーキシング効果の発現メカニ ズムは, 硬さ変化と密接に関係していることが推察される.

$$
\text { 4. 考察 }
$$

\section{$4 \cdot 1$ ひずみ時効能}

オ一ステナイト系ステンレス鋼にはひずみ時効が存在す ることが明らかにされている，そこで，本供試材のひずみ 時効能について調べた. 約 10\%の引張ひずみを与えたのち, $110^{\circ} \mathrm{C}$ で 5 時間加熱し, 再び引張試験を行った. その結果

Table 1 Mechanical properties.

\begin{tabular}{|c|c|c|c|c|}
\hline Material & $\begin{array}{c}0.2 \% \\
\text { proof stress } \\
(\mathrm{MPa})\end{array}$ & $\begin{array}{c}\text { Tensile } \\
\text { strength } \\
(\mathrm{MPa})\end{array}$ & $\begin{array}{c}\text { Elongation } \\
(\%)\end{array}$ & $\begin{array}{c}\text { Vickers } \\
\text { hardness } \\
H V\end{array}$ \\
\hline SUS304 & 298 & 594 & 69 & 192 \\
\hline SUS316 & 211 & 560 & 66 & 134 \\
\hline
\end{tabular}

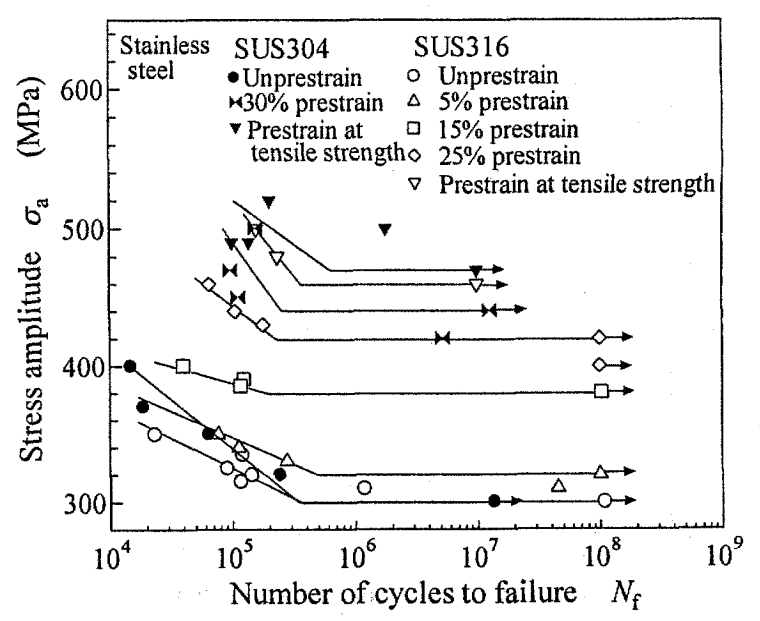

Fig.1 $S$-N diagram for austenitic stainless steels. 


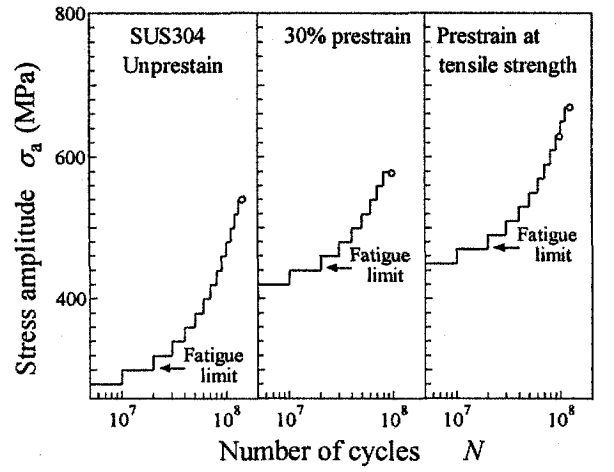

Fig.2 Stress-incremental fatigue test results in SUS304.

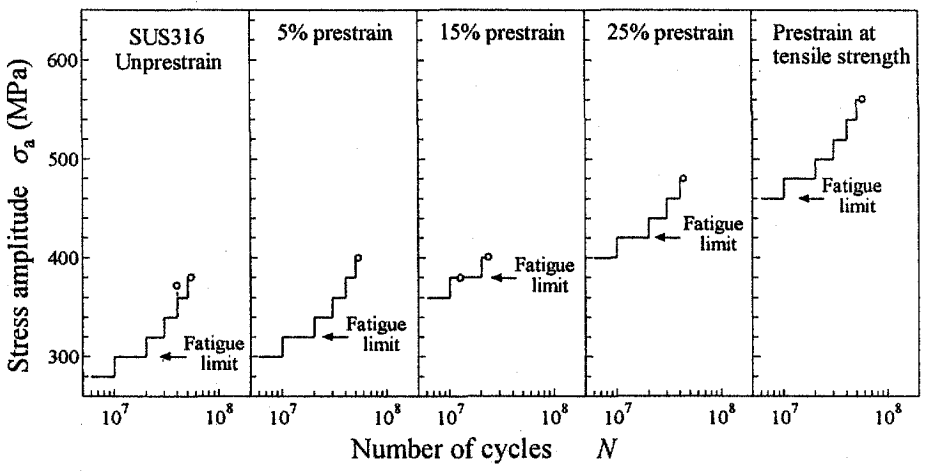

Fig.3 Stress-incremental fatigue test results in SUS316.

Table 2 Vickers hardness after stress incremental fatigue test.

(a)SUS304

\begin{tabular}{|c|c|c|c|}
\hline SUS304 & Unprestrain & $30 \%$ & $\begin{array}{c}\text { At tensile } \\
\text { strength }\end{array}$ \\
\hline Before coaxing test & 192 & 247 & 335 \\
\hline After coaxing test & 307 & 323 & 357 \\
\hline
\end{tabular}

(b)SUS316

\begin{tabular}{|c|c|c|c|c|c|}
\hline SUS316 & Unprestrain & $5 \%$ & $15 \%$ & $25 \%$ & $\begin{array}{c}\text { At tensile } \\
\text { strength }\end{array}$ \\
\hline Before coaxing test & 137 & 177 & 214 & 251 & 302 \\
\hline After coaxing test & 228 & 282 & 237 & 321 & 335 \\
\hline
\end{tabular}

を Fig.4 に示す. SUS304 はひずみ時効をほとんど示さず, 降伏応力の上昇は認められないのに対して, SUS316 はひ ずみ時効を示し，降伏応力は顕著に増加する．この結果か ら，SUS316 のコーキシング効果にはひずみ時効も関与し ていることが示唆される。

\section{4-2 加工誘起マルテンサイト変態}

オーステナイト系ステンレス鋼では加工誘起マルテンサ イト変態が生ずることが知られている。そこで，両材につ いてX線回折法によりマルテンサイト変態の有無を調べた. Fig.5に SUS304 無予ひずみ材の応力漸増試験後の試験片表 面で測定された X 線回折結果を示す. 図から明らかなよう に， $\alpha$ 相のピークが検出され，加工誘起マルテンサイト変 態が生じていることがわかった。この結果から，SUS304 のコーキシング効果には加工誘起マルテンサイト変態が関 与していることが考えられる。一方 SUS316 の場合, X 線 回折法により 5〜15\%予ひずみ材ではマルテンサイトは検 出されず, 25\%予ひずみ材では EBSD 解析により約 2\%のマ ルテンサイトが検出された：このことから，SUS316 のコ ーキシング効果には, 加工誘起マルテンサイト変態は重要 な役割を果たしていないと考えられる.

以上述べてきたことから，コーキシング効果の発現に対

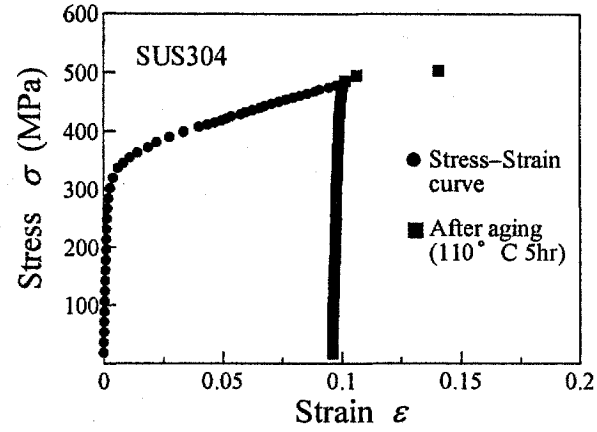

(a)SUS304

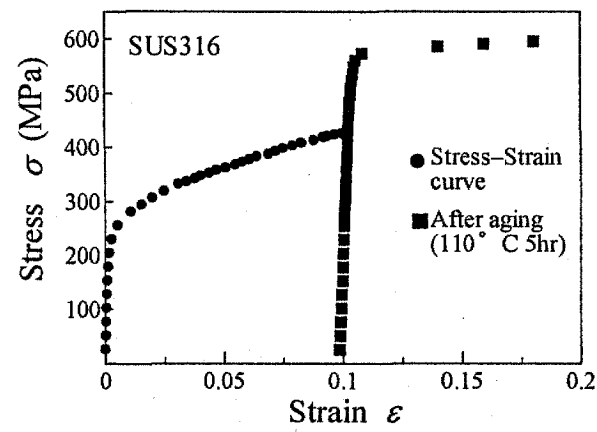

(b) SUS316

Fig.4 Strain age hardening effect in SUS304 and SUS316.

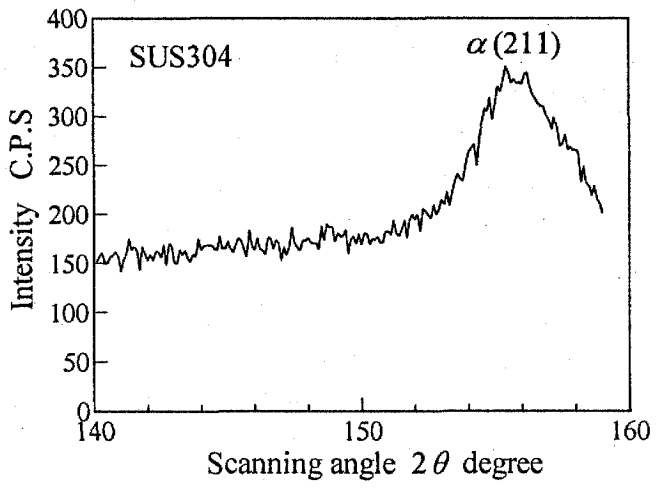

Fig.5 X-ray diffraction pattern for a unprestrained specimen in SUS304, indicating presence of martensite phase.

して, SUS304 では加工誘起マルテンサイト変態が支配的 な役割を果たしていると考えられる.一方 SUS316 の場合， 小さい予ひずみでは加工硬化またはひずみ時効が主因であ り，予ひずみが大きくなると加工誘起マルテンサイト変態 も寄与すると考えられる。

\section{5. 結 言}

本研究ではオーステナイト系ステンレス鋼 SUS304 およ び SUS316 のコーキシング効果に及ぼす予ひずみの影響と その発現メカニズムについて検討した. その結果, SUS304 の場合，予ひずみの増加に伴い破断応力が上昇した，明瞭 に加工誘起マルテンサイト変態が測定されたことから，コ 一キシング効果の発現に加工誘起マルテンサイト変態が支 配的な役割を演じていると判断された. 一方 SUS316 の場 合，15\%予ひずみ材では一旦顕著な破断応力の増加は見ら れなくなったが, その後予ひずみの増加に伴って再び破断 応力は増加した，予ひずみが小さい場合，加工硬化または ひずみ時効が，予ひずみが大きい場合，それに加えて加工 誘起マルテンサイト変態も関与していると考えられた。

(参考文献省略) 